\title{
AJANKOHTAISTA
}

\section{Uusi monitieteinen tutkimusryhmä tarkastelee hyvää ja kestävää vanhuutta}

Kestävä kehitys ja erilaiset kestävyysnäkökulmat ovat ajankohtaisia ja tärkeitä aiheita maailmanlaajuisesti. Mutta mikä on kestävyyden ja ikääntymisen suhde? Millainen ikääntyminen on kestävää?

Tampereen yliopiston monitieteellinen tutkimusryhmämme on ottanut tavoitteekseen selvittää, mitä on hyvä ja kestävä vanhuus, voiko ikääntyminen olla kestävää ja miten sitä voisi arvioida ja mitata. Tieteenaloista ryhmässä ovat edustettuina terveydenhuollon digitalisaatio ja data-analytiikka, terveystieteet ja gerontologia, sosiaali- ja terveyspolitiikka sekä aerosolifysiikka. Kestävän kehityksen ja hyvän ikääntymisen tarkastelu perinteiset tieteenalarajat rikkomalla mahdollistaa ilmiöiden moniulotteisen tarkastelun ja uusien oivallusten syntymisen. Tavoitteenamme on muodostaa entistä laajempi kuva siitä, mitkä tekijät vaikuttavat hyvään ikääntymiseen ja millä keinoin voimme tukea hyvää ikääntymistä kestävän kehityksen ulottuvuudet huomioiden.

\section{Kestävyyden eri ulottuvuudet}

Kestävä kehitys on moniulotteinen käsite, jolle voidaan antaa lukuisia määritelmiä. Kestävyyttä voidaan tarkastella erilaisten, toisiinsa kytköksissä olevien ulottuvuuksien tai osa-alueiden avulla. Minkälaista olisi sosiaalisesti, ekologisesti, taloudellisesti sekä kulttuurillisesti kestävä hyvä ikääntyminen?

Ekologisella kestäryydellä tarkoitetaan luonnon monimuotoisuuden turvaamista ja säilyt- tämistä tuleville sukupolville. Ekologisesti kestävä ikääntyminen voisi tarkoittaa esimerkiksi terveyttä edistävään ja sairauksia ennaltaehkäisevään toimintaan panostamista sekä hiilineutraaleita, biohajoavia ja kiertotalouteen pohjautuvia hoiva- ja hoitoratkaisuja.

Sosiaalisella kestävyydellä on lukuisia määritelmiä, mutta karkeasti sillä tarkoitetaan demokraattisia ja oikeudenmukaisia yhteisöjä, jotka tukevat ihmisten hyvinvointia. Ikääntyneiden kohdalla keskeisiä sosiaalisen kestävyyden näkökulmia ovat esimerkiksi hyvinvointipalveluiden toteutuminen, riittävä toimeentulo, turvallisuus sekä sosiaalinen yhteenkuuluvuus ja osallisuus. Lisäksi sosiaalisesti kestävään ikääntymiseen voidaan lukea ikään liittyvän syrjinnän vähentäminen.

Taloudelliseen kestävyyteen on perinteisesti liitetty talouskasvu. Kestävän kehityksen näkökulmasta talouskasvu ei perustu varantojen hävittämiseen, vaan taloudessa on huomioitava ympäristökuormituksen minimoiminen. Ikääntyneen väestön palvelutarpeiden vähentäminen ja lykkääminen myöhäisemmäksi on paitsi inhimillisestä näkökulmasta tärkeää myös taloudellisen kestävyyden näkökulmasta merkityksellistä, sillä näin voidaan hallita sosiaali- ja terveydenhuollon menoja.

Kulttuurillista kestävyyttä voidaan tulkita lukuisin eri tavoin. Sen voidaan ajatella merkitsevän kulttuurin tuotteiden suojelua, kestävyyttä tavoittelevaa työkalua tai tietoista muutosprosessia. Kulttuurillisen kestävyyden näkökulmasta vanhuus on yhteiskunnalle kulttuurinen voimavara. 


\section{Kestävä ikääntyminen ja Agenda 2030}

Kestävän kehityksen yhteydessä viitataan usein YK:n kestävän kehityksen toimintaohjelmaan, Agenda 2030:een, joka sisältää 17 globaalia tavoitetta. Näiden tavoitteiden toteutumista mitataan lukuisilla erilaisilla indikaattoreilla (YK 2015). Agenda 2030:n tavoitteissa sekä tarkemmissa indikaattoreissa ikääntyneet mainitaan vain lyhyesti, vaikka useassa tavoitteessa huomioidaan erikseen muita ikäryhmiä.
Ikääntyneitä tarkastellaan köyhyyden vähentämisen yhteydessä, kun tavoitellaan kaikenikäisten köyhyydessä elävien määrän vähentämistä. Sukupuolten tasa-arvon kohdalla tarkastellaan ikääntyneiden palkattomaan kotityöhön ja hoivaan käyttämää aikaa. Lisäksi turvallisen, edullisen, luotettavan ja kestävän liikennejärjestelmän edellytetään huomioivan erityisesti muun muassa ikääntyneiden tarpeet. (Tilastokeskus 2021; YK 2021.) (Taulukko 1.)

Taulukko 1. YK:n kestävän kehityksen globaalit tavoitteet (Tilastokeskus 2021; YK 2021).

\begin{tabular}{|c|c|}
\hline YK:n kestävän kehityksen tavoite & Ikääntyneiden näkökulma \\
\hline Ei köyhyyttä & $\begin{array}{l}\text { Tavoitteena kaikenikäisten köyhyydessä elävien määrän } \\
\text { vähentäminen. Tarkastellaan mm. yli 75-vuotiaita. }\end{array}$ \\
\hline Ei nälkää & Ei erityishuomiota ikääntyneisiin \\
\hline Terveyttä ja hyvinvointia & Ei erityishuomiota ikääntyneisiin \\
\hline Hyvä koulutus & Ei erityishuomiota ikääntyneisiin \\
\hline Sukupuolten tasa-arvo & $\begin{array}{l}\text { Tavoitteena tunnustaa palkaton hoito- ja kotityö ja antaa } \\
\text { sille arvo. Tarkastellaan mm. yli } 65 \text {-vuotiaiden palkattomaan } \\
\text { kotityöhön ja hoivaan käyttämää aikaa. }\end{array}$ \\
\hline Puhdas vesi ja sanitaatio & Ei erityishuomiota ikääntyneisiin \\
\hline Edullista ja puhdasta energiaa & Ei erityishuomiota ikääntyneisiin \\
\hline Ihmisarvoista työtä ja talouskasvua & Ei erityishuomiota ikääntyneisiin \\
\hline $\begin{array}{l}\text { Kestävää teollisuutta, innovaatioita ja } \\
\text { infrastruktuuria }\end{array}$ & Ei erityishuomiota ikääntyneisiin \\
\hline Eriarvoisuuden vähentäminen & Ei erityishuomiota ikääntyneisiin \\
\hline Kestävät kaupungit ja yhteisöt & $\begin{array}{l}\text { Tavoitteena turvallinen, edullinen, luotettava ja kestävä } \\
\text { liikennejärjestelmä, kiinnitetään erityistä huomiota mm. } \\
\text { ikääntyneiden tarpeisiin. }\end{array}$ \\
\hline Vastuullista kuluttamista & Ei erityishuomiota ikääntyneisiin \\
\hline Ilmastotekoja & Ei erityishuomiota ikääntyneisiin \\
\hline Vedenalainen elämä & Ei erityishuomiota ikääntyneisiin \\
\hline Maanpäällinen elämä & Ei erityishuomiota ikääntyneisiin \\
\hline $\begin{array}{l}\text { Rauha, oikeudenmukaisuus ja hyvä } \\
\text { hallinto }\end{array}$ & Ei erityishuomiota ikääntyneisiin \\
\hline Yhteistyö ja kumppanuus & Ei erityishuomiota ikääntyneisiin \\
\hline
\end{tabular}

Kestävyyttä ja ikääntymistä tarkastellaan harvoin samanaikaisesti, vaikka väestön ikääntyminen on maailmanlaajuisesti yhteiskuntiin vaikuttava kehityskulku. Elinikä on pidentynyt Suomessa kuten muissakin kehittyneissä maissa. Vuonna 2020 Suomessa elinajanodote oli miehillä noin 79 vuotta ja naisilla noin 85 vuot- ta. Vastaavat luvut vuonna 1970 olivat miehillä 66 vuotta ja naisilla 74 vuotta. (Suomen virallinen tilasto 2021.) Yhä useampi saa elää entistä korkeampaan ikään. On ennustettu, että vuonna 2030 Suomen väestöstä 26 prosenttia on yli 65-vuotiaita. Erityisesti vanhoista vanhimpien määrä on kasvanut ja sen ennustetaan kasva- 
van edelleen. (Suomen virallinen tilasto 2019.) Ikääntyneen väestön määrän kasvaessa heidän merkityksensä kestävän kehityksen toteutumisessa kasvaa entisestään. Silti etenkin julkisessa keskustelussa ikääntyneistä puhutaan kestävyyden näkökulmasta pääasiassa taloudellisena taakkana. Saavuttaaksemme kestävän kehityksen tavoitteita ikääntymistä ja ikääntynyttä väestöä voi ja tulisi tarkastella myös muiden kestävyyden ulottuvuuksien kuin taloudellisen kestävyyden näkökulmasta.

Tutkimusryhmämme on kiinnostunut siitä, mitä on hyvä ja kestävä vanhuus. Korkeaa ikää on pidetty yhtenä hyvän elämän mittarina. Elinajanodotteen ohella on tärkeää tarkastella myös sitä, kuinka suuri osa odotettavissa olevista elinvuosista on terveitä ja toimintakykyisiä. Tutkimuksessa on esimerkiksi havaittu, että vaikka yli 90-vuotiaiden ja sitä vanhempien toimintakykyiset elinvuodet ovat eliniän kasvaessa lisääntyneet, eivät vuodet heikentyneen toimintakyvyn kanssa ole vähentyneet (Enroth ym. 2020). Terveys ja toimintakyky eivät ole kuitenkaan hyvän ikääntymisen ainoita määrittäjiä; monisairaskin ihminen voi kokea ikääntyneensä hyvin. Hyvä ikääntyminen ei välttämättä tarkoita hyvää ikääntymistä kestävyyden näkökulmasta. Toisaalta ne eivät myöskään ole toisiaan poissulkevia.

\section{YK:n Agenda 2030 ja "puuttuva vanhuus"}

Kuten aiemmin totesimme, YK:n Agenda 2030 -toimintaohjelmassa näkökulma ikääntyneisiin ja heidän tarpeisiinsa kestävän kehityksen näkökulmasta on hyvin suppea (taulukko 1). Tarkemmissa alatavoitteissa mainitaan joitakin erityisiä väestöryhmiä mutta ei ikääntyneitä.

Kestävän kehityksen tavoitteisiin kuuluu terveyden ja hyvinvoinnin edistäminen, mutta Agenda 2030:n indikaattoreissa erityishuomiota ei ole kiinnitetty ikäntyneiden ihmisten terveyden ja toimintakyvyn ylläpitoon, vaikka sairauksien ja toimintakyvyn rajoitteiden tiedetään yleistyvän iän myötä. Ikääntyneiden terveyden ja toimintakyvyn ylläpito on erittäin merkityksellistä erityisesti sosiaalisesti ja taloudellisesti kestävän kehityksen kannalta. Sairauksia ja toimintakyvyn laskua ennaltaehkäisevät ja toimintakykyä ylläpitävät toimet ovat merkittävässä roolissa palvelutarpeen ja siihen liittyvien kustannusten näkökulmasta.

Innovaatioihin ja infrastruktuureihin liittyvässä tavoitteessa ikääntyneisiin ei ole kiinnitetty huomiota, vaikka digitalisaatio ja dataanalytiikka ovat monelta osin tukemassa ikääntyneiden sairauksien varhaista diagnostiikkaa ja sitä kautta toimintakyvyn ylläpitoa ja kotona asumisen mahdollistamista (ks. esim. Covenant on Demographic Change 2021; European Commission 2021). Myös eriarvoisuuden vähentämiseen sekä yhteistyöhön ja kumppanuuteen liittyvissä tavoitteissa ikäihmisten huomioiminen olisi tärkeää erityisesti sosiaalisen kestävyyden kannalta. Toimintakyvyltään hyväkuntoisia eläkeikäisiä voidaan tukea aktiivisessa yhteiskuntaan osallistumisessa työuran päättymisen jälkeen ja rakentaa sitä kautta sosiaalista yhteenkuuluvuutta ja osallisuutta.

Ilmastotekoihin liittyvien tavoitteiden näkökulmasta tiedetään jo paljon elinympäristön vaikutuksesta terveyteen ja toimintakykyyn. Esimerkiksi ilman pienhiukkasille altistuneilla on korkeampi ennenaikainen kuolleisuus sekä riski sairastua sydän- ja verisuonisairauksiin, erilaisiin syöpiin ja Alzheimerin tautiin (esim. Wu ym. 2015; Pun ym. 2017; Finch 2018). Uusimpien tietojen mukaan aiempaa pienempien pienhiukkaspitoisuuksien on arvioitu olevan terveydelle haitallisia (WHO 2021). Koska pienhiukkasaltistus lisää sairastavuutta, se lisää myös esimerkiksi sosiaali- ja terveyspalvelujen käyttöä. Siten ympäristö ja ilmanlaatu eivät ole yhteydessä vain ihmisten sairastavuuteen ja elämisen laatuun, vaan myös yhteiskunnallisiin kustannuksiin ja hyvinvointivaltion rajallisten resurssien käyttöön. 


\section{Tavoitteena hyvän ja kestävän vanhuuden viitekehys}

Hyvän elämän mahdollistaminen mahdollisimman kestävällä tavalla edellyttää monien eri tekijöiden huomioimista. Ajattelemme, että hyvään ja kestävään vanhuuteen kuuluu terveyden lisäksi sosiaalinen vuorovaikutus ja osallisuus, koettu elämän mielekkyys, turvallisuuden tunne ja suhde ympäristöön. Hyvän ja kestävän vanhuuden käsite ottaa huomioon myös tulevat sukupolvet. (Kuvio 1.)

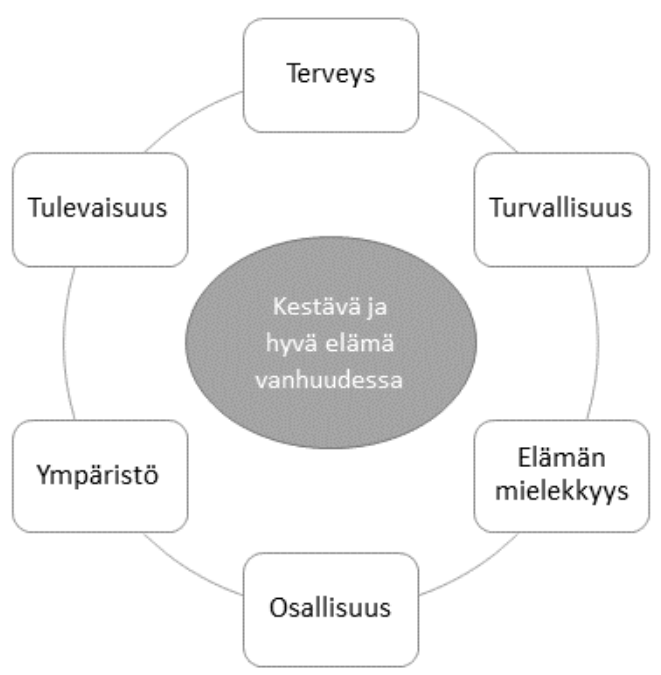

Kuvio 1. Hyvän ja kestävän vanhuuden elementit.

Tutkimusryhmämme tarkoituksena on tunnistaa ja kartoittaa sellaisia tekijöitä, jotka vaikuttavat hyvään ja kestävään vanhuuteen. Laajennamme perinteistä elämäntapatekijöiden ja terveyteen liittyvien tekijöiden tarkastelua, sillä pohdimme myös esimerkiksi elämänaikaisten elinolosuhteiden, sosiaalisen ympäristön ja osallistumisen merkitystä hyvän ja kestävän vanhuuden näkökulmasta Selvitämme, miten näitä tekijöitä voisi arvioida, mitata ja yhdistää hyödyntämällä digitalisaatiota ja modernia data-analytiikkaa. Tavoitteenamme on tuottaa alustava viitekehys, jota voitaisiin käyttää työkaluna suunniteltaessa päätöksentekoa eri tasoilla. Viitekehystä voitaisiin hyödyntää esimerkiksi sosiaali- ja terveyspolitiikassa, interventioiden kehittämisessä ja arvioinnissa sekä ennaltaehkäisevissä toimissa. Lisäksi tavoitteenamme on laajentaa kuvaa kestävän kehityksen ulottuvuuksista ja nostaa esiin ikääntynyt väestö, joka nykyisissä kestävän kehityksen tavoitteissa vaikuttaa lähes täysin unohtuneen.

\section{Mark van Gils}

Lääketieteen ja terveysteknologian tiedekunta, Tampereen yliopisto

\section{Antti Kallonen}

Lääketieteen ja terveysteknologian tiedekunta, Tampereen yliopisto

\section{Jenni Kulmala}

Yhteiskuntatieteiden tiedekunta, Tampereen yliopisto

\section{Mari Aaltonen}

Yhteiskuntatieteiden tiedekunta, Tampereen yliopisto

\section{Jutta Pulkki}

Yhteiskuntatieteiden tiedekunta, Tampereen yliopisto

\section{Panu Karjalainen}

Tekniikan ja luonnontieteiden tiedekunta, Tampereen yliopisto

\section{Heino Kuuluvainen}

Tekniikan ja luonnontieteiden tiedekunta, Tampereen yliopisto

\section{Vilhelmiina Lehto-Niskala}

Yhteiskuntatieteiden tiedekunta, Tampereen yliopisto

Tutkimusryhmämme on saanut siemenrahoitusta Tampereen yliopistossa toimivalta Sustainable Wellfare Systems-tutkimusohjelmalta. Tutkimusohjelman tavoitteena on monitieteisen byvinvointijärjestelmien tutkimuksen vabvistaminen Tampereen yliopistossa. Objelma saa rahoituksensa Suomen Akatemian profilointirahoituksen kautta. 


\section{Kirjallisuus}

Covenant on Demographic Change. Towards an age-friendly Europe. EU funded projects and studies. 2021. Internet: https://www.agefriendlyeurope.org/relevant-projects (viitattu 7.10.2021).

Enroth L, Raitanen J, Halonen P, Tiainen K, Jylhä M. Trends of physical functioning, morbidity, and disability-free life expectancy among the oldest old: six repeated cross-sectional surveys between 2001 and 2018 in the Vitality 90+ Study. J Gerontol A Biol Sci Med Sci 2020;76(7): 122733. https://doi.org/10.1093/gerona/glaa144

European Commission. European Innovation Partnership on Active and Healthy Ageing. 2021. Internet: https://ec.europa.eu/eip/ageing/home_ en.html (viitattu 7.10.2021).

Finch C. The role of air pollution in aging and disease. London: Academic Press, 2018. https://doi.org/10.1016/B978-0-12-8131022.05001-9

Pun VC, Kazemiparkouhi F, Manjourides J, Suh HH. Long-term PM2.5 exposure and respiratory, cancer, and cardiovascular mortality in older US adults. Am J Epidemiol 2017;186(8):961-9. https://doi.org/10.1093/aje/kwx166

Suomen virallinen tilasto. Väestöennuste 2019-2070. Suomen virallinen tilasto, 2019. Internet: https://www.stat.fi/til/vaenn/2019/ vaenn_2019_2019-09-30_tie_001_fi.html (viitattu 9.9.2021).

Suomen virallinen tilasto. Vastasyntyneen elinajanodote sukupuolen mukaan. Suomen virallinen tilasto, 2021. Internet: https://pxnet2.stat.fi/ PXWeb/pxweb/fi/StatFin/StatFin__vrm_kuol/ statfin_kuol_pxt_12am.px/ (viitattu 9.9.2021).
Tilastokeskus. Kestävän kehityksen YK-indikaattorit - Agenda2030. 2021. Internet: https://www. stat.fi/tup/kestavan-kehityksen-yk-indikaattorit-agenda2030.html (viitattu 16.9.2021).

YK. Transforming our world: the 2030 Agenda for Sustainable Development. Resolution adopted by the General Assembly on 25 September 2015. United Nations, 2015. Internet:

http://www.un.org/ga/search/view_doc.asp?symbol=A/RES/70/1\&Lang=E (viitattu 16.9.2021).

YK. Global indicator framework for the Sustainable Development Goals and targets of the 2030 Agenda for Sustainable Development. United Nations General Assembly, 2021. Internet: https://unstats.un.org/sdgs/indicators/Global\%20Indicator\%20Framework\%20 after\%202021\%20refinement_Eng.pdf (viitattu 16.9.2021).

World Health Organization. WHO global air quality guidelines: particulate matter (PM2.5 and PM10), ozone, nitrogen dioxide, sulfur dioxide and carbon monoxide. World Health Organization, 2021.

https://apps.who.int/iris/handle/10665/345329

Wu YC, Lin YC, Yu HL, Chen JH, Chen TF, Sun Y, Wen LL, et al. Association between air pollutants and dementia risk in the elderly. Alzheimer's \& Dementia: Diagnosis, Assessment \& Disease Monitoring 2015;1:220-8. https://doi.org/10.1016/j.dadm.2014.11.015 